\title{
Quantitative assessment of indica rice germination to hydropriming, hormonal priming and polyethylene glycol priming
}

Rambod Abiri ${ }^{1}$, Noor Azmi Shaharuddin ${ }^{1 *}$, Mahmood Maziah ${ }^{1}$,

Zetty Norhana Balia Yusof ${ }^{1}$, Narges Atabaki ${ }^{2}$, Mahbod Sahebi ${ }^{3}$, and Parisa Azizi ${ }^{3}$

\section{ABSTRACT}

Seed priming is a useful technique which improves seed germination parameters. The present investigation was conducted to evaluate some of the most important germination parameters such as total germination, germination rate, mean germination time, average speed, germination percentage (GP), germination vigor index (GVI), relative frequency, plumule fresh and dry weight, radical fresh and dry weight, plumule and radical length, leaf and root proline content of six indica rice (Oryza sativa L.) varieties, including MR219, MR219-4, MR219-9, MR220, MR159, and MR 211 under hydro-, hormonal- and polyethylen glycol (PEG)- priming conditions. The highest germination parameters were achieved under the hydro-priming treatment, at $18 \mathrm{~h} \mathrm{(100 \% ),}$ $6 \mathrm{~h}(100 \%), 18 \mathrm{~h}(90.3 \%), 12 \mathrm{~h}(91.6 \%), 18 \mathrm{~h}(86.6 \%)$, and $18 \mathrm{~h}(78.3 \%)$ for the genotypes MR219, MR219-4, MR2199, MR220, MR159, and MR211, respectively. The best germination feedback of the rice varieties under the hormonal priming were observed in $50 \mathrm{mg} \mathrm{L}^{-1}$ abscisic acid (ABA), 10 $\mathrm{mg} \mathrm{L}^{-1}$ gibberellic acid-3 $\left(\mathrm{GA}_{3}\right), 50 \mathrm{mg} \mathrm{L}^{-1}$ indole-3-acetic acid (IAA), $50 \mathrm{mg} \mathrm{L}^{-1} \mathrm{GA}_{3}, 100 \mathrm{mg} \mathrm{L}^{-1} \mathrm{ABA}$, and $10 \mathrm{mg} \mathrm{L}^{-1}$ $\mathrm{GA}_{3}$ for the genotypes MR219, MR219-4, MR219-9, MR220, MR159 and MR211, respectively. The rice varieties showed different responses to various levels of PEG in which MR219, MR219-4 and MR219-9 responded positively to higher PEG levels, while MR220, MR159 and MR211 showed better feedback under lower PEG concentrations. These outcomes comply with the higher tolerance of MR219, MR219-9 and MR219-4 varieties to drought stress.

Key words: PEG-priming, hormonal priming, hydropriming, Oryza sativa, proline.

${ }^{1}$ Universiti Putra Malaysia, Faculty of Biotechnology and Biomolecular Sciences, 43400 UPM Serdang, Selangor DE, Malaysia. *Corresponding author (noorazmi@upm.edu.my).

${ }^{2}$ Islamic Azad University, Science and Research Branch, 1477893855, Tehran, Iran.

${ }^{3}$ Universiti Putra Malaysia, Institute of Tropical Agriculture, 43400 UPM Serdang, Selangor DE, Malaysia.

Received: 7 June 2016.

Accepted: 1 October 2016.

doi: $10.4067 /$ S0718-58392016000400001

\section{INTRODUCTION}

Seed vigor is a vital aspect of seed quality that affects plant germination, growth and development. Using high quality seeds can lead to increasing plant yield, especially under environmental stress such as drought and salinity. The quality of seeds is estimated by various parameters, mostly by seed germination, seed vigor, and purity (Xie et al., 2014).

Plant growth regulators (PGRs), as organic compounds, are induced in small concentrations in crops. Despite the low concentration of plant hormones, these components play a vital role in growth, development and yield of plants (Cothren and Oosterhuis, 2010). Presoaking of seeds with the best phytohormones concentration leads to a high rate of generation and growth, especially, during adverse environmental conditions. This process is probably facilitated by the accumulation of nutrients through a raise in the physiological activities and root proliferation. Some investigations suggest that priming with indole acetic acid (IAA), gibberellic acid $\left(\mathrm{GA}_{3}\right)$ and ascorbic acid increases early growth, seedling establishment, germination rate, plant growth, and grain quantity and quality (Anosheh et al., 2011).

Polyethylene glycol (PEG) is a polyether compound with high molecular weight that can be utilized to induce high osmotic pressures (Aguilar-Benítez et al., 2014). Seeds pretreatment experiments under PEG show that the polyether can affect moisture availability in the germination medium. Analysis of the modification under such a condition shows that the germination in the presence of PEG is similar to that in soil under stress situation (Gharoobi et al., 2012). Proline, a proteinogenic amino acid, displays a compatible solute in plants osmotic regulation by acting as an enzyme protectant. Furthermore, proline stabilizes cellular and membrane structures under adverse conditions, detoxifies free radicals by forming long-lived adducts with them, and affects solubility of different proteins by interacting with their hydrophobic residues (Szabados and Savoure, 2010). Although accumulation of proline in plants under stress conditions has a protective function; nonetheless, the correlation between plants under abiotic stress and proline is not always obvious. Also, proline accumulation in rice (Oryza sativa L.) under drought stress has been approved. However, rice as a model plant displays a significant role in human dietary needs in all over the world, but undesirable conditions consisting of abiotic and biotic stresses can limit its production (Wang et al., 2010). According to Pittelkow et al. (2014), rice yield can be reduced up to $60 \%$ during growth under moderate stress 
conditions. However in the recent years, researchers aimed to breed the drought-tolerant rice cultivars through classic genetic and modern biotechnological approaches (Nam et al., 2014). To this end, the present study was conducted to investigate the effect of various seed priming agents on different Malaysian rice factors, in germination and early growth stages. Additionally, the effects of PEG treatment as a chemical drought inducer on the morphoand physiological traits, and proline level of Malaysian rice have been identified.

\section{MATERIALS AND METHODS}

\section{Plant material}

Seeds of six indica rice (Oryza sativa L.) varieties MR219, MR219-4, MR219-9, MR220, MR159, and MR211 were obtained from the Malaysian Agricultural Research Development Institute (MARDI), Serdang, Selangor, Malaysia. The selected mature rice seeds of each variety were dehulled manually. All seeds were then surface sterilized through immersion in $70 \%$ ethyl alcohol for 30 s. Subsequently, the ethanol was discarded and seeds were washed once with distilled water, then $40 \%$ sodium hypochlorite was added and seeds were stirred along with this solution for $20 \mathrm{~min}$. Finally, the sterilized seeds were rinsed five times with sterile double-distilled water.

\section{Hydro- and hormonal-priming}

Twenty seeds of each rice variety were soaked for $1 \mathrm{~h}$ in petri dishes with two layers of Whatman filter papers moistened with $10 \mathrm{~mL}$ distilled water. Afterwards, all seeds were permitted to grow at room temperature in different hydro-priming time interval (control, 6, 12, $18,24,30,40$ and $50 \mathrm{~h}$ ). Different concentrations of kinetin, indole-3-acetic acid (IAA), abscisic acid (ABA), naphthaleneacetic acid (NAA), salicylic acid, ascorbic acid, and $\mathrm{GA}_{3}$ (Table 1) were used in different periods of time to evaluate the effect of PGRs on presoaking of rice seeds (Table 2) (Wahyuni et al., 2003).

The presoaking times were also used according to the best periods of time achieved by the initial hydro-priming experiments for each genotype, separately. The first records of germination were taken on the second day of culturing, while the last were counted on the ninth day. The germination percentage $(\mathrm{G} \%)$ and time to $50 \%$ germination
Table 2. Soaking times of seeds according to the earlier results of hydro-priming in different rice varieties.

\begin{tabular}{lcccccc}
\hline Varieties & MR219 & MR219-4 & MR219-9 & MR220 & MR159 & MR211 \\
\hline $\begin{array}{l}\text { Best soaking } \\
\text { time }\end{array}$ & $18 \mathrm{~h}$ & $6 \mathrm{~h}$ & $24 \mathrm{~h}$ & $12 \mathrm{~h}$ & $18 \mathrm{~h}$ & $18 \mathrm{~h}$ \\
\hline
\end{tabular}

(T50) was calculated according to the modified formula by (Farooq et al., 2006a):

$$
T 50=t_{i}+\left[\left(N / 2-n_{i}\right)\left(t_{j}-t_{i}\right) /\left(n_{j}-n_{i}\right)\right]
$$

where $\mathrm{N}$ is the final number of germinated seeds and $n_{i}$ and $\mathrm{n}_{\mathrm{j}}$ are cumulative number of seeds germinated by adjacent counts at times $t_{i}$ and $t_{j}$ when $n_{i}<N / 2<n_{j}$.

Mean germination time (MGT) was calculated according to the modified equation of Roberts and Ellis (1989):

$$
M G T=\Sigma D_{n} / \Sigma n
$$

where $n$ is the number of seeds germinated on day $D$, and $D$ is the number of days counted from the beginning of germination.

The germination vigor index (GVI) was calculated based on the equation created by Clune and Copeland (1999) and Sikder et al. (2009). Seeds were assumed as germinated when radicle length appeared to be about $2 \mathrm{~mm}$.

$$
G V I=A 1 / T 1+A 2 / T 2+\ldots+A n / T n
$$

Where $A$ is the number of germinated seeds; $T$ is time (d) corresponding to $A$, and $n$ is final days.

\section{PEG priming}

Twenty seeds of each rice variety were placed in petri dishes on two layers of Whatman filter papers nr 1 . To make solutions with the osmotic potentials ( $\left.\Psi_{\mathrm{S}}\right)$ consisting of the control (no PEG), -0.4, -0.8 and -1.2 MPa treatments, polyethylene glycol (PEG 6000) was dissolved in distilled water based on Michel and Kaufmann formula (Michel and Kaufmann, 1973):

$$
\begin{gathered}
\Psi_{S}=-\left(1.18 \times 10^{-2}\right) C-\left(1.18 \times 10^{-4}\right) C+\left(2.67 \times 10^{-4}\right) C T+ \\
\left(8.39 \times 10^{-7}\right) C 2 T
\end{gathered}
$$

where $C$ is the concentration of PEG-6000 in $\mathrm{g} \mathrm{kg}^{-1} \mathrm{H}_{2} \mathrm{O}$ and $T$ is the temperature in ${ }^{\circ} \mathrm{C}$.

The osmotic potential of PEG solution (-0.4, -0.8 and -1.2 $\mathrm{MPa})$ were prepared by using 161, 241 and $302 \mathrm{~g} \mathrm{PEG} \mathrm{L}^{-1}$. The petri dishes were put in a germinator at $25 \pm 2{ }^{\circ} \mathrm{C}$ and irrigated with distilled water. The filter papers of each petridish were replaced every $2 \mathrm{~d}$ to inhibit salt accumulation

\begin{tabular}{|c|c|c|c|c|c|}
\hline $\mathrm{Nr}$ & Treatment & $\mathrm{Nr}$ & Treatment & $\mathrm{Nr}$ & Treatment \\
\hline T1 & Control & $\mathrm{T} 11$ & Abscisic acid $50 \mathrm{mg} \mathrm{L}^{-1}$ & $\mathrm{~T} 21$ & Salicylic acid $100 \mathrm{mg} \mathrm{L}^{-1}$ \\
\hline $\mathrm{T} 2$ & Kinetin $10 \mathrm{mg} \mathrm{L}^{-1}$ & $\mathrm{~T} 12$ & Abscisic acid $75 \mathrm{mg} \mathrm{L}^{-1}$ & $\mathrm{~T} 22$ & Ascorbic acid $10 \mathrm{mg} \mathrm{L}^{-1}$ \\
\hline T3 & Kinetin $50 \mathrm{mg} \mathrm{L}^{-1}$ & $\mathrm{~T} 13$ & Abscisic acid $100 \mathrm{mg} \mathrm{L}^{-1}$ & $\mathrm{~T} 23$ & Ascorbic acid $50 \mathrm{mg} \mathrm{L}^{-1}$ \\
\hline $\mathrm{T} 4$ & Kinetin $75 \mathrm{mg} \mathrm{L}^{-1}$ & $\mathrm{~T} 14$ & 1-Naphthaleneacetic acid $10 \mathrm{mg} \mathrm{L}^{-1}$ & $\mathrm{~T} 24$ & Ascorbic acid $75 \mathrm{mg} \mathrm{L}^{-1}$ \\
\hline T5 & Kinetin $100 \mathrm{mg} \mathrm{L}^{-1}$ & $\mathrm{~T} 15$ & 1-Naphthaleneacetic acid $50 \mathrm{mg} \mathrm{L}^{-1}$ & $\mathrm{~T} 25$ & Ascorbic acid $100 \mathrm{mg} \mathrm{L}^{-1}$ \\
\hline T6 & Indole-3-acetic acid $10 \mathrm{mg} \mathrm{L}^{-1}$ & $\mathrm{~T} 16$ & 1-Naphthaleneacetic acid $75 \mathrm{mg} \mathrm{L}^{-1}$ & $\mathrm{~T} 26$ & Gibberellic acid $10 \mathrm{mg} \mathrm{L}^{-1}$ \\
\hline $\mathrm{T} 7$ & Indole-3-acetic acid $50 \mathrm{mg} \mathrm{L}^{-1}$ & $\mathrm{~T} 17$ & 1-Naphthaleneacetic acid $100 \mathrm{mg} \mathrm{L}^{-1}$ & $\mathrm{~T} 27$ & Gibberellic acid $50 \mathrm{mg} \mathrm{L}^{-1}$ \\
\hline T8 & Indole-3-acetic acid $75 \mathrm{mg} \mathrm{L}^{-1}$ & $\mathrm{~T} 18$ & Salicylic acid $10 \mathrm{mg} \mathrm{L}^{-1}$ & $\mathrm{~T} 28$ & Gibberellic acid $75 \mathrm{mg} \mathrm{L}^{-1}$ \\
\hline Т9 & Indole-3-acetic acid $100 \mathrm{mg} \mathrm{L}^{-1}$ & $\mathrm{~T} 19$ & Salicylic acid $50 \mathrm{mg} \mathrm{L}^{-1}$ & $\mathrm{~T} 29$ & Gibberellic acid $100 \mathrm{mg} \mathrm{L}^{-1}$ \\
\hline $\mathrm{T} 10$ & Abscisic acid $10 \mathrm{mg} \mathrm{L}^{-1}$ & $\mathrm{~T} 20$ & Salicylic acid $75 \mathrm{mg} \mathrm{L}^{-1}$ & & \\
\hline
\end{tabular}
(Dennis et al., 2000). The seeds were considered as germinated when radicle length became about $2 \mathrm{~mm}$. The first records of germination were taken on the second day

Table 1. Different concentration of hormonal priming. 
of the experiment and continued every $24 \mathrm{~h}$. The recording process was finished when numbers of germinated seeds were found to be unchanged for $2 \mathrm{~d}$. This almost happened on the $9^{\text {th }}$ day of the experiment for all rice varieties. Germination rate (GR) was calculated based on the equation created by Ellis and Roberts (1980a; 1980b):

$$
G R=\sum n / t
$$

where $n$ is germinated seed number at time $t$, $\mathrm{t}$ is days of experiment.

Average germination time (AGT) was calculated according to the modified equation of Roberts and Ellis (1989):

$$
A G T=t=\frac{\left[\sum_{i=1}^{k} n i t i\right]}{\sum_{\mathrm{i}=1}^{k} n i}
$$

where $t$ is average incubation time, $n i$ is number of germinated seeds per day, $t i$ is time of incubation (d).

Average speed of germination: $v=1 / t$, where $t$ is average time of germination.

The germination percentage $(\mathrm{G} \%)=\sum \frac{\mathrm{n} g}{\mathrm{n} t}, n g$ is number of germinated seeds and $n t$ is total number of seeds.

Seedling vigor index (SVI) was counted according to the modified formula of Abdul-Baki and Anderson (1973):

$\mathrm{SVI}=$ [seedling length $(\mathrm{cm}) \times$ germination percentage $]$

The relative frequency of germination (Fr) was calculated according to (Labouriau and Pacheo, 1978):

$$
\text { Relative frequency: } \mathrm{Fr}=\frac{n i}{\sum_{i=1}^{k} n i}
$$

where $n i$ is number of germinated seeds per day, $\Sigma n i$ is total number of germinated seeds.

Mean root and shoot lengths at the end of germination period were measured per replicate. After drying each replicate over night at $70{ }^{\circ} \mathrm{C}$ in the oven, seedling dry weights were recorded with an electronic balance to get the stable weight (Afzal et al., 2005). For statistical analysis, germinating percentage data were converted to $\arcsin \sqrt{x} / 100$.

\section{Proline content determination}

Proline content was determined using ninhydrin acid reagent according to Bates et al. (1973). Plant samples (0.5 g) were homogenized with $5 \mathrm{~mL}$ sulfosalicylic acid $(3 \%, \mathrm{w} / \mathrm{v})$ in a cold mortar and pestle. The homogenate was centrifuged at $10000 \mathrm{~g}$ for $15 \mathrm{~min}$, and $2 \mathrm{~mL}$ supernatant was mixed with $2 \mathrm{~mL}$ glacial acetic acid and $2 \mathrm{~mL}$ acid ninhydrin (acid-ninhydrin was prepared by warming $1.25 \mathrm{~g}$ ninhydrin in $30 \mathrm{~mL}$ glacial acetic acid and $20 \mathrm{~mL} 6 \mathrm{M}$ phosphoric acid, with agitation, until dissolved). Kept cool (stored at $4{ }^{\circ} \mathrm{C}$ ), the reagent remains stable for $24 \mathrm{~h}$. After agitation, the reaction mixture was incubated at $100{ }^{\circ} \mathrm{C}$ for $30 \mathrm{~min}$ till the a red brick color were developed. After cooling, 4 $\mathrm{mL}$ toluene was added to each tube and vortexed for $30 \mathrm{~s}$. The chromophore containing toluene was separated, and the absorbance was read at $520 \mathrm{~nm}$ in spectrophotometer against toluene blank. The concentration of proline was quantified using the standard curve of L-proline.

\section{Statistical analyses}

The analysis of the main effects of the stress was based on the ANOVA and comparisons of means were conducted using Duncan's Multiple Range Test at $\mathrm{p} \leq 0.01$ by SAS software, version 9.4 (SAS Institute, Cary, North Carolina, USA). The results were expressed in terms of mean \pm standard error (SE) with three replicates.

\section{RESULTS AND DISCUSSION}

\section{ANOVA of hydro-priming effects}

The ANOVA revealed that the response of varieties to hydro-priming treatment was significant ( $\mathrm{p} \leq 0.01)$ in terms of total germination, MGT, GP, and GVI (Table 3). The ANOVA also showed a significant difference among the studied varieties in terms of T50 in 5\% probability level (Table 3). Accordingly, the interaction of variety and time for all traits were found to be significant in 1\% level (Table $3)$. Nonsignificant difference was observed among the replicates. Such an observation has been considered as a sign of accuracy of the experiment (Talei et al., 2012).

\section{Mean comparison results}

The highest G\% were obtained in 18 (100\%), 6 (100\%), $18(90.3 \%), 12(91.6 \%), 18(86.6 \%)$, and $18 \mathrm{~h}(78.3 \%)$ for the genotypes MR219, MR219-4, MR219-9, MR220, MR159 and MR211, respectively. By increasing the hydro-priming times with water, the fluctuation trend were observed for all the treats. On the other hand, mean comparison results showed that the highest MGT belonged to control (1.25 d) and the lowest belonged $18 \mathrm{~h}(0.45)$ for MR219. For MR214-4, the highest MGT belonged to 50 $\mathrm{h}(1.008)$ and the lowest belonged to $6 \mathrm{~h}(0.45)$. MR2199 showed the highest MGT at $12 \mathrm{~h}(0.9)$ and the lowest amount at $24 \mathrm{~h}(0.52)$. For MR220, the highest and lowest amounts were belonged to control (0.73) and $12 \mathrm{~h}(0.491)$, respectively. The highest and lowest MGT for MR159 were belonged to $50(0.93)$ and $18 \mathrm{~h}(0.51)$, respectively. MR211 demonstrated the highest and lowest amounts at the 50 (1.13) and $18 \mathrm{~h}$, respectively. Analysis of GVI demonstrated a fluctuating trend in different times. In this respect, the highest GVI was obtained when seeds were hydro primed for $18,6,24$, and $40 \mathrm{~h}, 12$ and $24 \mathrm{~h}, 18$ and $24 \mathrm{~h}$, and 18

Table 3. ANOVA of hydro-priming effect on germination and growth of different rice varieties.

\begin{tabular}{lrccllc}
\hline $\begin{array}{l}\text { Source of } \\
\text { variation }\end{array}$ & df & $\begin{array}{c}\text { Total } \\
\text { germination }\end{array}$ & T50 & MGT & \multicolumn{1}{c}{ G\% } & \multicolumn{1}{c}{ GVI } \\
\hline Variety & 5 & $45.8^{* *}$ & $0.32^{*}$ & $0.207^{* *}$ & $0.1447^{* *}$ & $1147.36^{* *}$ \\
Time & 7 & $109.3^{* *}$ & $8.4^{* *}$ & $0.401^{* *}$ & $2.601^{* *}$ & $2733.1^{* *}$ \\
Replicate & 2 & $0.023^{\text {ns }}$ & $0.88^{\text {ns }}$ & $0.0004^{\text {ns }}$ & $0.00007^{\text {ns }}$ & $0.69^{\text {ns }}$ \\
Variety $\times$ Time & 35 & $16.4^{* *}$ & $0.8^{* *}$ & $0.56^{* *}$ & $2.7860^{* *}$ & $412.36^{* *}$ \\
Error & 94 & 0.524 & 0.139 & 0.0035 & 0.151 & 13.10 \\
Total & 143 & - & - & - & - & - \\
\hline CV, \% & & 5.15 & 9.527 & 8.68 & 3.94 & 5.15 \\
\hline
\end{tabular}

*, ${ }^{* *}$ Significant at the 0.05 and 0.01 probability levels, respectively. Ns: nonsignificant, T50: 50\% germination, MGT: mean germination time, G\%: germination percentage, GVI: germination vigor index. 
and $24 \mathrm{~h}$ for MR219, MR219-4, MR219-9, MR220, MR159 and MR211, respectively. The highest GVI was achieved by the MR219 seeds which were primed for 18 and $24 \mathrm{~h}$ in water. Consequently, the mentioned primed times created a separate cluster in the mean comparison table (Table 4). The lowest range of GVI was gained by seeds of MR219 when they had been treated with water for $50 \mathrm{~h}$. The results of hydro-priming for 30 and $40 \mathrm{~h}$, as well as the control were the same and the GVI in 6 and $12 \mathrm{~h}$ were totally different and created dependent groups separately (Table 4).

On the other hand, this study confirmed that regardless of different levels of hydro-priming, all of the investigated traits behave differently depending on the cultivars. In line with this, the results of other studies proves that different factors such as the chemical composition of seed, seed cotyledons and endosperm can affect the seed permeability (Aguilar-Benítez et al., 2014). Aguilar-Benítez et al. (2014) reported that large sized seeds with large size have a higher germination percentage and need less time to germinate. The advantages of large seeds can be associated with the embryo size and their capacity to provide more energy. Generally, under normal, and stress conditions such as salinity, matric stress and low temperature, the vigor of primed seeds increases (Pant and Bose, 2016). However, the results of some investigations comply with the positive effect of priming on the acceleration of germination, and improving the germination-related traits which finally leads to increasing the plant growth. On the other hand, grain quality and quantity, early growth, and final germination percentage have been improved in the primed seeds of various plants (Wahid et al., 2008; Hamidi and Pirasteh-Anosheh, 2013).

\section{Hormonal priming}

ANOVA and Duncan's multiple comparison test of the PGRpriming showed that the effects of variety, PGRs, different concentrations of PGRs and the interactions between them are significant ( $\mathrm{p} \leq 0.01$ ) on total germination, T50, MGT, G\%, and GVI (Table 5). The mean comparison of hormonal priming treatments revealed that there are significant differences $(\mathrm{p} \leq 0.01)$ among the six rice varieties in terms of both G\% and GVI (Table 6).

These results confirmed that the MR219 performed as the best variety in the T11 and T21 treatments, whereas, the lowest amount of G\% was found in T8, T13, T18, T25 and T6. On the other hand, T25 showed the lowest GVI for MR219. According to the results, MR219-4 obtained the highest G\% and GVI in T26 and T19 whereas, T1 led to the weakest germination in this variety. The situation of MR219-9 was different, where the highest and lowest G\% and GVI were achieved under T7 and T1, respectively. Similar to other varieties, T1 produced the lowest rates of G\% and GVI in MR220, while T27 resulted in the highest rate of G\% and GVI. Unlike the other varieties, MR159 obtained the highest G\% and GVI under T13 and T27. Remarkably, for MR159 two different treatments led to the lowest rate of G\% and GVI, in which T4 and T1 caused the lowest $\mathrm{G} \%$ and GVI, respectively.

Seed priming is an effective tool for obtaining vigor and emergence of seedlings under both suboptimal and optimal condition (Farooq et al., 2006a).

Rice hormonal priming with ethylene and $\mathrm{GA}_{3}$ demonstrated an increase in number of internodes, and embryonic tissues elongation, whereas ABA priming

Table 4. Mean comparison of germination percentage (G\%) and germination vigor index (GVI) of different rice varieties under different hydro-priming condition.

\begin{tabular}{|c|c|c|c|c|c|c|c|c|c|c|c|c|}
\hline \multirow[b]{2}{*}{ Treatment } & \multicolumn{2}{|c|}{ MR219 } & \multicolumn{2}{|c|}{ MR219-4 } & \multicolumn{2}{|c|}{ MR219-9 } & \multicolumn{2}{|c|}{ MR220 } & \multicolumn{2}{|c|}{ MR159 } & \multicolumn{2}{|c|}{ MR211 } \\
\hline & $\mathrm{G} \%$ & GVI & $\mathrm{G} \%$ & GVI & $\mathrm{G} \%$ & GVI & $\mathrm{G} \%$ & GVI & $\mathrm{G} \%$ & GVI & $\mathrm{G} \%$ & GVI \\
\hline 0 & $0.64 \mathrm{~g}$ & $1.17 \mathrm{~g}$ & $1.04 \mathrm{~d}$ & $3.06 \mathrm{f}$ & $0.93 c$ & $2.32 \mathrm{c}$ & $0.90 \mathrm{~d}$ & $2.17 d$ & $0.97 b$ & $2.80 \mathrm{de}$ & $0.70 \mathrm{~d}$ & $2.07 \mathrm{de}$ \\
\hline 6 & $0.73 \mathrm{f}$ & $2.17 \mathrm{ef}$ & $1.57 \mathrm{a}$ & $5.66 \mathrm{a}$ & $1.04 \mathrm{~b}$ & $3.33 b c$ & $1.04 \mathrm{c}$ & $3.56 b c$ & $0.99 b$ & $3.50 \mathrm{~cd}$ & $0.85 c$ & $3.17 \mathrm{~b}$ \\
\hline 12 & $1.10 \mathrm{c}$ & $4.26 c$ & $1.24 b$ & $5.18 b$ & $0.78 \mathrm{~d}$ & $2.36 \mathrm{c}$ & $1.28 \mathrm{a}$ & $5.31 \mathrm{a}$ & $1.10 \mathrm{a}$ & $4.47 b$ & $0.96 b c$ & $3.80 \mathrm{~b}$ \\
\hline 18 & $1.57 \mathrm{a}$ & $7.75 \mathrm{a}$ & $1.10 \mathrm{~cd}$ & $4.37 \mathrm{~d}$ & $1.24 \mathrm{a}$ & $4.90 \mathrm{a}$ & $0.92 d$ & $4.06 \mathrm{~b}$ & $1.19 \mathrm{a}$ & $5.20 \mathrm{a}$ & $1.08 \mathrm{a}$ & $4.70 \mathrm{a}$ \\
\hline 24 & $1.24 \mathrm{~b}$ & $7.08 \mathrm{a}$ & $1.17 \mathrm{bc}$ & $4.70 \mathrm{c}$ & $1.17 \mathrm{a}$ & $4.93 \mathrm{a}$ & $1.17 b c$ & $5.03 \mathrm{a}$ & $1.17 \mathrm{a}$ & $3.40 \mathrm{a}$ & $1.06 \mathrm{ab}$ & $5.00 \mathrm{a}$ \\
\hline 30 & $0.97 \mathrm{~d}$ & $3.20 \mathrm{~d}$ & $1.02 \mathrm{~d}$ & $3.40 \mathrm{e}$ & $1.15 \mathrm{a}$ & 4.34ab & $1.15 \mathrm{ab}$ & $4.25 \mathrm{~b}$ & $1.10 \mathrm{a}$ & $3.70 b c$ & $0.88 \mathrm{c}$ & $2.31 \mathrm{~d}$ \\
\hline 40 & $0.81 \mathrm{e}$ & $2.51 \mathrm{e}$ & $0.90 \mathrm{e}$ & $2.80 \mathrm{f}$ & $1.02 \mathrm{~b}$ & $3.94 \mathrm{ab}$ & 1.19ab & $4.19 b$ & $0.97 b$ & $2.97 \mathrm{~cd}$ & $0.86 b$ & $2.39 \mathrm{~d}$ \\
\hline 50 & $0.65 \mathrm{~g}$ & $1.62 \mathrm{gf}$ & $0.73 \mathrm{f}$ & $1.90 \mathrm{~g}$ & $0.83 \mathrm{~d}$ & $2.98 b c$ & $0.93 d$ & $3.20 \mathrm{c}$ & $0.76 \mathrm{c}$ & $2.36 \mathrm{e}$ & $0.68 \mathrm{~d}$ & $1.51 \mathrm{e}$ \\
\hline
\end{tabular}

Different letters indicate significant difference among accessions according to Duncan's multiple range tests ( $\mathrm{p} \leq 0.05$ ).

Table 5. ANOVA of hormonal or plant growth regulators (PGR) priming effect on germination and growth of the six rice varieties.

\begin{tabular}{|c|c|c|c|c|c|c|}
\hline Source of variation & $\mathrm{df}$ & Total germination & $\mathrm{T} 50$ & MGT & $\mathrm{G} \%$ & GVI \\
\hline Variety & 5 & $58.21^{* *}$ & $9.52^{* *}$ & $0.23^{* *}$ & $0.14^{* *}$ & $7.4^{* *}$ \\
\hline PGR & 7 & $7.58^{* *}$ & $1.85^{\text {** }}$ & $0.05^{* *}$ & $0.019^{* *}$ & $0.96^{* *}$ \\
\hline PGR concentration & 3 & $5.49^{* *}$ & $0.83^{* *}$ & $0.028^{* *}$ & $0.014^{* *}$ & $1.10^{* *}$ \\
\hline Replicate & 2 & $0.027^{\mathrm{ns}}$ & $0.02^{\mathrm{ns}}$ & $0.00007^{\mathrm{ns}}$ & $0.00008^{\mathrm{ns}}$ & $0.001^{\mathrm{ns}}$ \\
\hline Variety $\times$ PGR & 35 & $6.38^{* *}$ & $1.63^{* *}$ & $0.031^{* *}$ & $0.017^{* *}$ & $1.05^{* *}$ \\
\hline Variety $\times$ Different PGR concentration & 15 & $3.53^{* *}$ & $0.55^{* *}$ & $0.022^{* *}$ & $0.009^{* *}$ & $0.31^{* *}$ \\
\hline PGR $\times$ Different PGR concentrations & 21 & $3.18^{* *}$ & $0.93^{* *}$ & $0.014^{* *}$ & $0.008^{* *}$ & $0.56^{* *}$ \\
\hline Variety $\times$ PGR $\times$ Different PGR concentrations & 105 & $4.65^{* *}$ & $1.13^{* *}$ & $0.023^{* *}$ & $0.012^{* *}$ & $0.81^{* *}$ \\
\hline Error & 382 & 0.011 & 0.003 & 0.00002 & 0.00003 & 0.0001 \\
\hline Total & 575 & - & - & - & - & - \\
\hline $\mathrm{CV}$ & - & 0.94 & 1.25 & 1.58 & 1.71 & 1.01 \\
\hline
\end{tabular}

* ${ }^{* *}$ Significant at the 0.05 and 0.01 probability levels, respectively. Ns: Nonsignificant. 
Table 6. Mean comparison of germination percentage (G\%) and germination vigor index (GVI) of six rice varieties based on plant growth regulators (PGR) priming treatments.

\begin{tabular}{|c|c|c|c|c|c|c|c|c|c|c|c|c|}
\hline \multirow[b]{2}{*}{ Traits } & \multicolumn{2}{|c|}{ MR219 } & \multicolumn{2}{|c|}{ MR219-4 } & \multicolumn{2}{|c|}{ MR219-9 } & \multicolumn{2}{|c|}{ MR220 } & \multicolumn{2}{|c|}{ MR159 } & \multicolumn{2}{|c|}{ MR211 } \\
\hline & G\% & GVI & G\% & GVI & G\% & GVI & G\% & GVI & G\% & GVI & $\mathrm{G} \%$ & GVI \\
\hline $\mathrm{T} 1$ & $0.88 \mathrm{e}$ & $2.70 \mathrm{~s}$ & $0.68 \mathrm{~g}$ & $1.76 \mathrm{r}$ & $0.68 \mathrm{~g}$ & $1.87 \mathrm{~s}$ & $0.63 \mathrm{~g}$ & $1.82 \mathrm{z}$ & $0.83 \mathrm{~d}$ & $1.82 \mathrm{z}$ & $0.73 \mathrm{e}$ & $1.88 \mathrm{t}$ \\
\hline $\mathrm{T} 2$ & $1.04 \mathrm{~b}$ & $3.80 \mathrm{c}$ & $0.93 b$ & $3.04 \mathrm{f}$ & $0.73 \mathrm{f}$ & $1.88 \mathrm{r}$ & $0.78 \mathrm{e}$ & $2.57 \mathrm{p}$ & $0.83 d$ & $2.57 \mathrm{p}$ & $0.73 \mathrm{e}$ & $1.88 \mathrm{t}$ \\
\hline $\mathrm{T} 3$ & $1.04 \mathrm{~b}$ & $3.80 \mathrm{c}$ & $0.88 \mathrm{c}$ & $2.88 \mathrm{~g}$ & $0.88 \mathrm{c}$ & $2.60 \mathrm{f}$ & $0.78 \mathrm{e}$ & $2.49 \mathrm{q}$ & $0.78 \mathrm{e}$ & $2.49 \mathrm{q}$ & $0.78 d$ & $2.01 \mathrm{r}$ \\
\hline $\mathrm{T} 4$ & $1.00 \mathrm{c}$ & $4.20 \mathrm{~b}$ & $0.83 d$ & $2.73 \mathrm{~h}$ & $0.83 d$ & $2.03 q$ & $0.88 \mathrm{c}$ & $3.11 \mathrm{e}$ & $0.73 f$ & $3.11 \mathrm{e}$ & $0.83 c$ & $2.51 \mathrm{~g}$ \\
\hline T5 & $0.93 \mathrm{~d}$ & $2.80 \mathrm{p}$ & $0.78 \mathrm{e}$ & $2.08 n$ & $0.88 \mathrm{c}$ & $2.53 \mathrm{k}$ & $0.83 d$ & $2.26 \mathrm{~s}$ & $0.83 d$ & $2.26 \mathrm{t}$ & $0.63 \mathrm{f}$ & $1.43 \mathrm{v}$ \\
\hline T6 & $0.88 \mathrm{e}$ & $2.80 \mathrm{n}$ & $0.73 f$ & $2.01 \mathrm{p}$ & $0.83 \mathrm{~d}$ & $2.12 \mathrm{n}$ & $0.73 f$ & $1.88 \mathrm{y}$ & $0.83 \mathrm{~d}$ & $1.88 \mathrm{y}$ & $0.78 \mathrm{~d}$ & $2.01 \mathrm{r}$ \\
\hline $\mathrm{T} 7$ & $0.99 \mathrm{c}$ & $3.50 \mathrm{e}$ & $0.83 d$ & 2.060 & $1.047 \mathrm{a}$ & $3.96 \mathrm{a}$ & $0.78 \mathrm{e}$ & $2.01 \mathrm{w}$ & $0.93 b$ & $2.01 \mathrm{w}$ & $0.78 \mathrm{~d}$ & $2.02 \mathrm{q}$ \\
\hline T8 & $0.83 \mathrm{f}$ & $2.30 \mathrm{u}$ & $0.83 d$ & $2.38 \mathrm{~m}$ & $0.88 \mathrm{c}$ & 2.461 & $0.88 \mathrm{c}$ & $3.01 \mathrm{~h}$ & $0.83 \mathrm{~d}$ & $3.01 \mathrm{~h}$ & $0.78 d$ & $1.90 \mathrm{~s}$ \\
\hline Т9 & $0.93 d$ & $3.30 \mathrm{~h}$ & $0.78 \mathrm{e}$ & $2.08 n$ & $0.83 \mathrm{~d}$ & $2.62 \mathrm{~g}$ & $0.93 b$ & $3.13 \mathrm{~d}$ & $0.73 f$ & $3.13 \mathrm{~d}$ & $0.83 \mathrm{c}$ & $2.55 \mathrm{~d}$ \\
\hline T10 & $0.99 \mathrm{c}$ & $3.50 \mathrm{f}$ & $0.83 d$ & 2.060 & $0.78 \mathrm{e}$ & $2.70 \mathrm{e}$ & $0.88 \mathrm{c}$ & $2.98 \mathrm{i}$ & $0.83 d$ & $2.98 \mathrm{i}$ & $0.78 d$ & $2.29 \mathrm{~m}$ \\
\hline T11 & $1.10 \mathrm{a}$ & $4.50 \mathrm{a}$ & $0.83 \mathrm{~d}$ & $2.62 \mathrm{i}$ & $0.73 \mathrm{e}$ & $2.08 \mathrm{o}$ & $0.83 d$ & $2.17 \mathrm{v}$ & $0.88 \mathrm{c}$ & $2.10 \mathrm{v}$ & $0.88 \mathrm{~b}$ & 2.311 \\
\hline T12 & $0.88 \mathrm{e}$ & $3.20 \mathrm{i}$ & $0.78 \mathrm{e}$ & $2.08 n$ & $0.83 d$ & $2.06 n$ & $0.78 \mathrm{e}$ & $1.92 \mathrm{x}$ & $0.88 \mathrm{c}$ & $1.92 \mathrm{x}$ & $0.83 c$ & $2.33 \mathrm{j}$ \\
\hline T13 & $0.83 \mathrm{f}$ & $2.30 \mathrm{u}$ & $0.83 d$ & 2.060 & $0.78 \mathrm{e}$ & $2.08 \mathrm{o}$ & $0.83 \mathrm{~d}$ & $2.22 \mathrm{u}$ & $0.99 a$ & $2.22 \mathrm{u}$ & $0.73 \mathrm{e}$ & $1.54 \mathrm{u}$ \\
\hline T14 & $0.99 \mathrm{c}$ & $2.75 p$ & $0.88 \mathrm{c}$ & $1.93 q$ & $0.83 d$ & $2.61 \mathrm{~h}$ & $0.88 \mathrm{c}$ & $2.79 \mathrm{~m}$ & $0.83 d$ & $2.79 \mathrm{~m}$ & $0.83 c$ & $2.35 \mathrm{i}$ \\
\hline T15 & $0.88 \mathrm{e}$ & $2.80 \mathrm{n}$ & $0.83 \mathrm{~d}$ & 2.060 & $0.88 \mathrm{c}$ & $2.88 \mathrm{c}$ & $0.93 b$ & $4.09 \mathrm{~b}$ & $0.88 \mathrm{c}$ & $4.01 \mathrm{~b}$ & $0.88 \mathrm{~b}$ & $2.87 \mathrm{c}$ \\
\hline T16 & $1.04 \mathrm{~b}$ & $3.80 \mathrm{c}$ & $0.88 \mathrm{c}$ & $3.36 \mathrm{c}$ & $0.88 \mathrm{c}$ & $2.37 \mathrm{~m}$ & $0.88 \mathrm{c}$ & $2.76 n$ & $0.83 \mathrm{~d}$ & $2.76 n$ & $0.83 c$ & $2.54 \mathrm{e}$ \\
\hline T17 & $0.93 \mathrm{~d}$ & $3.07 \mathrm{k}$ & $0.83 \mathrm{~d}$ & 2.060 & $0.83 \mathrm{~d}$ & $2.61 \mathrm{~h}$ & $0.88 \mathrm{c}$ & $2.93 \mathrm{k}$ & $0.93 b$ & $2.93 \mathrm{k}$ & $0.83 c$ & $2.37 \mathrm{~h}$ \\
\hline T18 & $0.83 \mathrm{f}$ & $2.73 \mathrm{r}$ & $0.88 \mathrm{c}$ & $3.20 \mathrm{~d}$ & $0.83 d$ & $2.12 \mathrm{n}$ & $0.88 \mathrm{c}$ & $2.93 \mathrm{k}$ & $0.88 \mathrm{c}$ & $2.93 \mathrm{k}$ & $0.88 \mathrm{~b}$ & $2.31 \mathrm{k}$ \\
\hline T19 & $0.88 \mathrm{e}$ & 3.011 & $0.93 b$ & $3.72 \mathrm{a}$ & $0.78 \mathrm{e}$ & 2.080 & $0.93 b$ & $3.06 \mathrm{f}$ & $0.88 \mathrm{c}$ & $3.06 \mathrm{f}$ & $0.83 c$ & $2.51 \mathrm{f}$ \\
\hline T20 & $0.99 \mathrm{c}$ & $3.50 \mathrm{~g}$ & $0.83 \mathrm{~d}$ & 2.060 & $0.83 \mathrm{~d}$ & $2.62 \mathrm{~g}$ & $0.83 \mathrm{~d}$ & 2.871 & $0.88 \mathrm{c}$ & 2.871 & $0.78 \mathrm{~d}$ & $2.24 n$ \\
\hline T21 & $1.14 \mathrm{a}$ & $4.30 \mathrm{a}$ & $0.93 b$ & $3.06 \mathrm{e}$ & $0.88 \mathrm{c}$ & 2.461 & $0.93 b$ & $3.35 \mathrm{c}$ & $0.93 b$ & $3.35 \mathrm{c}$ & $0.73 \mathrm{e}$ & $1.88 \mathrm{t}$ \\
\hline $\mathrm{T} 22$ & $0.88 \mathrm{e}$ & $3.20 \mathrm{j}$ & $0.83 \mathrm{~d}$ & $2.62 \mathrm{i}$ & $0.83 d$ & $2.06 \mathrm{p}$ & $0.83 \mathrm{~d}$ & $3.01 \mathrm{~g}$ & $0.93 b$ & $3.01 \mathrm{~g}$ & $0.83 c$ & $2.88 \mathrm{~b}$ \\
\hline $\mathrm{T} 23$ & $0.88 \mathrm{e}$ & $2.80 \mathrm{n}$ & $0.88 \mathrm{c}$ & 2.451 & $0.93 b$ & $3.00 \mathrm{~b}$ & $0.73 \mathrm{f}$ & $1.54 \mathrm{z}$ & $0.88 \mathrm{c}$ & $1.54 \mathrm{a}$ & $0.83 \mathrm{c}$ & $2.88 b$ \\
\hline $\mathrm{T} 24$ & $0.93 \mathrm{~d}$ & $2.86 \mathrm{p}$ & $0.88 \mathrm{c}$ & $2.47 \mathrm{k}$ & $0.88 \mathrm{c}$ & $2.56 \mathrm{i}$ & $0.83 \mathrm{~d}$ & 2.871 & $0.83 \mathrm{~d}$ & 2.871 & $0.88 b$ & $3.01 \mathrm{a}$ \\
\hline T25 & $0.83 \mathrm{f}$ & $2.20 \mathrm{v}$ & $0.88 \mathrm{c}$ & $3.37 \mathrm{~b}$ & $0.83 d$ & $2.61 \mathrm{~h}$ & $0.88 \mathrm{c}$ & $2.95 \mathrm{j}$ & $0.73 \mathrm{f}$ & $2.95 \mathrm{j}$ & $0.83 \mathrm{c}$ & $2.49 \mathrm{~g}$ \\
\hline T26 & $0.83 \mathrm{f}$ & $2.73 \mathrm{r}$ & $1.04 \mathrm{a}$ & $2.56 \mathrm{j}$ & $0.83 d$ & $2.12 \mathrm{n}$ & $0.88 \mathrm{c}$ & 2.610 & $0.78 \mathrm{e}$ & 2.610 & $0.93 \mathrm{a}$ & $2.88 \mathrm{~b}$ \\
\hline T27 & $0.93 \mathrm{~d}$ & $2.90 \mathrm{~m}$ & $0.93 b$ & $3.06 \mathrm{e}$ & $0.73 f$ & $1.54 \mathrm{t}$ & $0.99 a$ & $4.10 \mathrm{a}$ & $0.83 \mathrm{~d}$ & $4.10 \mathrm{a}$ & $0.78 d$ & $2.13 p$ \\
\hline T28 & $1.00 \mathrm{c}$ & $2.80 \mathrm{o}$ & $0.88 \mathrm{c}$ & $2.56 \mathrm{j}$ & $0.88 \mathrm{c}$ & $2.87 \mathrm{~d}$ & $0.83 \mathrm{~d}$ & $2.20 \mathrm{~s}$ & $0.88 \mathrm{c}$ & $2.26 \mathrm{~s}$ & $0.83 \mathrm{c}$ & $2.55 \mathrm{~d}$ \\
\hline T29 & $0.88 \mathrm{e}$ & $2.51 \mathrm{t}$ & $0.83 d$ & 2.060 & $0.88 \mathrm{c}$ & $2.54 \mathrm{j}$ & $0.88 \mathrm{c}$ & $2.40 \mathrm{r}$ & $0.83 \mathrm{~d}$ & $2.43 \mathrm{r}$ & $0.78 \mathrm{~d}$ & 2.210 \\
\hline
\end{tabular}

Different letters indicate significant difference among accessions according to Duncan's multiple range test ( $\mathrm{p} \leq 0.05$ ).

stimulated mesocotyl elongation (Tamaki et al., 2015). Priming of sunflower with the priming agents lead to the improvement of shoot length, root length as well as shoot and root dry weight (Wahid et al., 2008). In the similar investigation which had been conducted to estimate the different priming efficiency of MR219, the highest amounts of tiller number, number of productive tillers and productive tillers per hill belonged to salicylic acid at 150 $\mathrm{mg} \mathrm{L}^{-1}$ and methyl jasmonate at $200 \mathrm{mg} \mathrm{L}^{-1}$, respectively. In the mentioned study, salicylic acid at $150 \mathrm{mg} \mathrm{L}^{-1}$ was introduced to be used as hormonal priming for higher productivity of MR219 rice in Malaysia (Kareem et al., 2013). In contrast to the above results, Wahyuni et al. (2013) reported that different responses of MR219 and MR84 rice varieties to various priming treatments depended on several factors such as sowing time, interaction between plant growth regulator and variety, as well as priming stages. In another study, cowpea seed treated with $5 \mathrm{mg} \mathrm{L}^{-1}$ $\mathrm{G}_{3} \mathrm{~A}_{3}$ and IAA displayed a significant increase in seedling growth and germination percentage cowpea. Nonetheless, by increasing concentrations of these PGRs, the mentioned traits decreased dramatically (Audi and Muhktar, 2009). Rice seeds do not live forever; and seed germination of seeds depends on both external and internal factors. Despite the dispersal of billions of rice seeds are dispersed annually, seed germination is intensely decreasing intensely due to diseases and dormancy.

\section{PEG priming}

A significant $(\mathrm{P}<0.01)$ effect of PEG treatments on different varieties were observed on the total germination, GR, AGT, average speed, G\%, SVI, relative frequency, plumule fresh weight, plumule dry weight, radical fresh weight, radical dry weight, plumule length, radical length, leaves proline, root proline, and root proline/shoot proline of all seeds with similar responses from six rice types (Table 7). In the current step of investigation, all the mentioned traits were reduced by increasing the PEG level (Table 8 ). The plumule fresh and dry weight, radical fresh and dry weigh, plumule and root length are of those critical parameters which severely decrease under abiotic stress. For this reason, investigation of these parameters are the most important subjects of studying plants in initial growth steps under stress (Jamil et al., 2006). Reduction in the above characteristics as a result of abiotic stress has been reported in a number of plant species such as wheat, rice and maize (Nam et al., 2014; Pittelkow et al., 2014; Pant and Bose, 2016). Althought the MR219-4, MR219-9 and MR219 seeds germinated in the higher PEG levels, the MR220 (-1.2 MPa), MR159 and MR211 (-0.8 and -1.2 MPa) seeds could not germinate at all (Table 8). Reportedly, the reduction in germination by increasing the PEG level was possibly due to high seed nutrient imbalance, toxic ions, and reduced soluble osmotic potential (Khodarahmpour et al., 2014). In contrast to all the above parameters, average 
Table 7. ANOVA of polyethylene glycol (PEG) effects on germination and growth parameters of six rice varieties.

\begin{tabular}{lcccccccccc}
\hline & df & TG & RG & AGT & AS & G\% & SVI & Fr & PFW & PDW \\
\hline Variety & 5 & $35.02^{* *}$ & $0.24^{* *}$ & $65.68^{* *}$ & $0.13^{* *}$ & $0.24^{* *}$ & $0.002^{* *}$ & $1.28^{* *}$ & $0.0038^{* *}$ & $0.001^{* *}$ \\
PEG & 3 & $795.84^{* *}$ & $5.52^{* *}$ & $12.32^{* *}$ & $0.05^{* *}$ & $3.34^{* *}$ & $0.002^{* *}$ & $0.54^{* *}$ & $0.012^{* *}$ & $0.0012^{* *}$ \\
Replicate & 2 & $0.59^{\text {ns }}$ & $0.004^{\text {ns }}$ & $18.1^{\text {ns }}$ & $0.0008^{\text {ns }}$ & $0.006^{\text {ns }}$ & $0.00007^{\text {ns }}$ & $0.40^{\text {ns }}$ & $0.0006^{\text {ns }}$ & $0.00004^{\text {ns }}$ \\
Variety $\times$ PEG & 15 & $10.7^{* *}$ & $0.077^{* *}$ & $29.1^{* *}$ & $0.009^{* *}$ & $0.07^{* *}$ & $0.0006^{* *}$ & $0.52^{* *}$ & $0.0005^{* *}$ & $0.0008^{* *}$ \\
Error & 46 & 0.43 & 0.003 & 3.9 & 0.001 & 0.002 & 0.000003 & 0.07 & 0.00007 & 0.0006 \\
Total & 71 & - & - & - & - & - & - & - & - \\
CV $\%$ & - & 11.23 & 11 & 35.25 & 23.31 & 12.50 & 17.95 & 35.83 & 3.03 & 15 \\
\hline
\end{tabular}

${ }^{*},{ }^{* *}$ Significant at the 0.05 and 0.01 probability levels, respectively. Ns: Nonsignificant.

TG: Total germination, GR: germination rate, AGT: average germination time, AS: average speed, G\%: germination percentage, SVI: seedling vigor index, Fr: relative frequency, PFW: plumule fresh weight, PDW: plumule dry weight.

Cont' Table 7:

\begin{tabular}{|c|c|c|c|c|c|c|c|c|}
\hline & df & RFW & RDW & PL & RL & LP & $\mathrm{RP}$ & RP/SP \\
\hline Variety & 5 & $0.0033^{* *}$ & $0.00004^{* *}$ & $2.66^{* *}$ & $0.22^{* *}$ & $10148.4^{* *}$ & $5335.72^{* *}$ & $1.57^{* *}$ \\
\hline PEG & 3 & $0.005^{* *}$ & $0.000002^{* *}$ & $2.42^{* *}$ & $0.25^{* *}$ & $8352.85^{* *}$ & $4996.1^{* *}$ & $3.49^{* *}$ \\
\hline Replicate & 2 & $0.000005^{\mathrm{ns}}$ & $0.00007^{\mathrm{ns}}$ & $0.16^{\mathrm{ns}}$ & $0.013^{\mathrm{ns}}$ & $30.7^{\mathrm{ns}}$ & $3.16^{\mathrm{ns}}$ & $0.015^{\mathrm{ns}}$ \\
\hline Variety $\times$ PEG & 15 & $0.000007^{* *}$ & $0.000006^{* *}$ & $0.21^{* *}$ & $0.016^{* *}$ & $6141.4^{* *}$ & $3322.2^{* * *}$ & $0.53^{* *}$ \\
\hline Error & 46 & 0.0000007 & 0.000002 & 0.087 & 0.43 & 23.32 & 7.86 & 0.02 \\
\hline Total & 71 & - & - & - & - & - & - & - \\
\hline $\mathrm{CV}$ & - & 1.3 & 1.5 & 31.9 & 2.60 & 11.97 & 9.54 & 14.8 \\
\hline
\end{tabular}

***:Significant at the 0.05 and 0.01 probability levels, respectively. Ns: Nonsignificant.

RFW: Radical fresh weight, RDW: radical dry weight, PL: plumule length, RL: radical length, LP: leaf proline, RP: root proline, RP/SP: ratio of root to shoot proline.

Table 8. Comparison effect of polyethylene glycol (PEG) priming on various traits of different indica rice varieties.

\begin{tabular}{|c|c|c|c|c|c|c|c|c|c|c|c|c|c|c|c|c|c|c|c|}
\hline & \multicolumn{4}{|c|}{ MR219 } & \multicolumn{4}{|c|}{ MR219-4 } & \multicolumn{4}{|c|}{ MR219-9 } & \multicolumn{3}{|c|}{ MR220 } & \multicolumn{2}{|c|}{ MR159 } & \multicolumn{2}{|c|}{ MR211 } \\
\hline & $\mathrm{C}$ & -0.4 & -0.8 & -1.2 & $\mathrm{C}$ & -0.4 & -0.8 & -1.2 & $\mathrm{C}$ & -0.4 & -0.8 & -1.2 & $\mathrm{C}$ & -0.4 & -0.8 & $\mathrm{C}$ & -0.4 & $\mathrm{C}$ & -0.4 \\
\hline TG & $14.3 \mathrm{a}$ & $3.6 \mathrm{~b}$ & $1.6 \mathrm{~b}$ & $1.3 \mathrm{~b}$ & $16.3 \mathrm{a}$ & $9 b$ & $6.4 \mathrm{c}$ & $1.6 \mathrm{~d}$ & $19.6 \mathrm{a}$ & $4.2 \mathrm{~b}$ & $3.5 b c$ & $1.6 \mathrm{c}$ & $12.1 \mathrm{a}$ & $3.6 \mathrm{~b}$ & $2.2 \mathrm{bc}$ & $17 \mathrm{a}$ & $8.3 b$ & $14.3 \mathrm{a}$ & $1.6 \mathrm{~b}$ \\
\hline GR & $1.16 \mathrm{a}$ & $0.3 b$ & $0.13 \mathrm{~b}$ & $0.11 b$ & $1.31 \mathrm{a}$ & $0.75 b$ & $0.55 \mathrm{c}$ & $0.13 \mathrm{~d}$ & $1.63 \mathrm{a}$ & $0.33 b$ & $0.25 b c$ & $0.13 c$ & $1.3 \mathrm{a}$ & $0.3 b$ & $0.16 b c$ & $1.41 \mathrm{a}$ & $0.69 \mathrm{~b}$ & $1.16 \mathrm{a}$ & $0.13 b$ \\
\hline AGT & $6.95 \mathrm{a}$ & $7.2 \mathrm{a}$ & $11.3 \mathrm{a}$ & $8.3 \mathrm{a}$ & $4.96 \mathrm{a}$ & $6.61 \mathrm{a}$ & $6.46 a$ & $10 \mathrm{a}$ & $9.1 \mathrm{a}$ & $5.48 \mathrm{a}$ & $5.6 \mathrm{a}$ & $9.3 \mathrm{a}$ & 5.1ab & $4.4 \mathrm{ab}$ & $7.9 \mathrm{a}$ & $5.12 \mathrm{~b}$ & $5.17 \mathrm{a}$ & $6.45 \mathrm{a}$ & $8.66 a$ \\
\hline AS & $0.14 \mathrm{a}$ & $0.14 b$ & $0.13 \mathrm{a}$ & $0.098 \mathrm{a}$ & $0.20 \mathrm{a}$ & $0.15 \mathrm{ab}$ & $0.15 \mathrm{ab}$ & $0.11 \mathrm{~b}$ & $0.1 \mathrm{a}$ & $0.11 \mathrm{a}$ & $0.17 \mathrm{a}$ & $0.11 \mathrm{a}$ & $0.19 \mathrm{a}$ & $0.2 \mathrm{a}$ & $0.15 \mathrm{a}$ & $0.195 \mathrm{a}$ & $0.193 b$ & $0.15 a$ & $0.12 \mathrm{a}$ \\
\hline $\mathrm{G} \%$ & $0.99 \mathrm{a}$ & $0.44 \mathrm{~b}$ & $0.28 b c$ & $0.25 \mathrm{c}$ & $1.12 \mathrm{a}$ & $0.73 b$ & $0.61 \mathrm{~b}$ & $0.28 \mathrm{c}$ & $1.49 \mathrm{a}$ & $0.46 \mathrm{~b}$ & $0.39 \mathrm{~b}$ & $0.28 b$ & $0.88 \mathrm{a}$ & $0.44 \mathrm{~b}$ & $0.31 \mathrm{~b}$ & $1.17 \mathrm{a}$ & $0.70 \mathrm{~b}$ & $0.99 \mathrm{a}$ & $0.28 b$ \\
\hline SVI & $28.3 \mathrm{a}$ & $5.56 \mathrm{~b}$ & $0.83 \mathrm{c}$ & $0.04 \mathrm{c}$ & $40.8 \mathrm{a}$ & $18.2 \mathrm{~b}$ & $10.4 \mathrm{c}$ & $1.66 \mathrm{~d}$ & $59.2 \mathrm{a}$ & $10.2 b$ & $4.5 c$ & $1.57 \mathrm{c}$ & $24.1 \mathrm{a}$ & $5.5 b$ & $2.5 b c$ & $42.5 \mathrm{a}$ & $12.5 b$ & $2.1 \mathrm{a}$ & $0.16 b$ \\
\hline $\mathrm{Fr}$ & $1.07 \mathrm{a}$ & $1.11 \mathrm{a}$ & $1.35 \mathrm{a}$ & $0.83 \mathrm{a}$ & $0.42 \mathrm{a}$ & $0.89 \mathrm{a}$ & $0.94 \mathrm{a}$ & $1.3 \mathrm{a}$ & $0.91 \mathrm{a}$ & $1.04 \mathrm{a}$ & $1.2 \mathrm{a}$ & $1.3 \mathrm{a}$ & $0.41 \mathrm{ab}$ & $0.8 \mathrm{ab}$ & $1.2 \mathrm{a}$ & $0.2 \mathrm{~b}$ & $0.7 \mathrm{a}$ & $0.93 \mathrm{a}$ & $1.33 \mathrm{a}$ \\
\hline PFW & $0.08 \mathrm{a}$ & $0.05 \mathrm{~b}$ & $0.02 \mathrm{c}$ & $0.01 d$ & $0.05 \mathrm{a}$ & $0.03 \mathrm{~b}$ & $0.01 \mathrm{c}$ & $0.01 \mathrm{c}$ & $0.10 \mathrm{a}$ & $0.8 b$ & $0.05 \mathrm{c}$ & $0.02 \mathrm{~d}$ & $0.02 \mathrm{a}$ & $0.01 \mathrm{~b}$ & $0.01 \mathrm{c}$ & $0.09 \mathrm{a}$ & $0.05 \mathrm{~b}$ & $0.04 \mathrm{a}$ & $0.03 \mathrm{~b}$ \\
\hline PDW & $0.005 \mathrm{a}$ & $0.002 b$ & $0.001 \mathrm{c}$ & $0.0007 \mathrm{~d}$ & $0.089 a$ & $0.006 \mathrm{~b}$ & $0.005 \mathrm{c}$ & $0.005 \mathrm{~d}$ & $0.0125 \mathrm{a}$ & $\mathrm{a} 0.0120 \mathrm{~b}$ & $0.010 \mathrm{c}$ & $0.008 \mathrm{~d}$ & $0.008 \mathrm{a}$ & $0.005 b$ & $0.002 \mathrm{c}$ & $0.004 \mathrm{a}$ & $0.002 \mathrm{~b}$ & $0.002 \mathrm{a}$ & $0.001 \mathrm{~b}$ \\
\hline RFW & $0.02 \mathrm{a}$ & $0.01 \mathrm{~b}$ & $0.01 \mathrm{~b}$ & $0.008 \mathrm{c}$ & $0.017 \mathrm{a}$ & $0.014 b$ & $0.012 \mathrm{c}$ & $0.01 d$ & $0.06 \mathrm{a}$ & $0.05 \mathrm{~b}$ & $0.04 \mathrm{c}$ & $0.03 \mathrm{~d}$ & $0.005 \mathrm{a}$ & $0.003 \mathrm{~b}$ & $0.002 \mathrm{c}$ & $0.01 \mathrm{a}$ & $0.012 b$ & $0.003 \mathrm{a}$ & $0.002 \mathrm{~b}$ \\
\hline RDW & $0.001 \mathrm{a}$ & $0.0008 \mathrm{~b}$ & $0.0007 \mathrm{c}$ & $0.0003 \mathrm{~d}$ & $0.006 \mathrm{a}$ & $0.005 b$ & $0.004 \mathrm{c}$ & $0.003 \mathrm{~d}$ & $0.001 \mathrm{c}$ & $0.0009 \mathrm{~d}$ & $0.007 \mathrm{a}$ & $0.005 b$ & $0.001 \mathrm{a}$ & $0.0003 b$ & $0.0002 \mathrm{c}$ & $0.002 \mathrm{a}$ & $0.001 \mathrm{~b}$ & $0.0009 \mathrm{a}$ & $0.0003 b$ \\
\hline PL $(\mathrm{cm})$ & ) $1.3 \mathrm{a}$ & $1.01 \mathrm{~b}$ & $0.7 \mathrm{c}$ & $0.3 \mathrm{~d}$ & $1.9 \mathrm{a}$ & $1.6 \mathrm{~b}$ & $1.4 \mathrm{c}$ & $1.2 \mathrm{~d}$ & $1.6 \mathrm{a}$ & $1.5 \mathrm{~b}$ & $1.3 \mathrm{c}$ & $1.2 \mathrm{~d}$ & $1.7 \mathrm{a}$ & $1.5 \mathrm{~b}$ & $1.2 \mathrm{c}$ & $1.0 \mathrm{a}$ & $1.2 \mathrm{a}$ & $0.9 \mathrm{a}$ & $0.4 \mathrm{~b}$ \\
\hline $\mathrm{RL}(\mathrm{cm}$ & n) $0.4 \mathrm{a}$ & $0.3 b$ & $0.1 \mathrm{c}$ & $0.09 \mathrm{~d}$ & $0.5 \mathrm{a}$ & $0.4 \mathrm{~b}$ & $0.3 \mathrm{c}$ & $0.2 \mathrm{~d}$ & $0.6 \mathrm{a}$ & $0.5 b$ & $0.3 \mathrm{c}$ & $0.2 \mathrm{~d}$ & $0.4 \mathrm{a}$ & $0.33 b$ & $0.2 \mathrm{c}$ & $0.3 \mathrm{a}$ & $0.3 \mathrm{a}$ & $0.1 \mathrm{a}$ & $0.08 \mathrm{~b}$ \\
\hline
\end{tabular}

Different letters indicate significant differences among the six rice varieties according to Duncan's multiple range tests $(\mathrm{p} \leq 0.05)$.

TG: Total germination, GR: germination rate, AGT: average germination time, AS: average speed, G\%: germination percentage, SVI: seedling vigor index, Fr: relative frequency, PFW: plumule fresh weight, PDW: plumule dry weight, RFW: radical fresh weight, RDW: radical dry weight, PL: plumule length, RL: radical length.

germination time was increased by increasing the PEG level in all varieties. Increment in the mean germination with the increasing of osmotic potential by $\mathrm{NaCl}$ and PEG were documented in rice, maize and safflower previously (Farooq et al., 2006b; Khodarahmpour et al., 2014).

The PEG content affected the proline accumulation in different rice varieties significantly. By increasing the PEG concentration, leaf and root proline contents of all varieties were increased (Figure 1). The highest leaf and root proline contents were observed in the highest level of PEG for each variety, whereas the lowest proline contents were found in the control treatments for all varieties. Remarkably, the proline content of roots were less than leaf proline in the six rice varieties. Additionally, MR219, MR219-4 and MR2199 showed the germination and proline reaction in all PEG treatments, while MR220 did not display growth in -1.2
MPa PEG. Meanwhile, MR159 and MR211 showed less resistance in response to higher levels of PEG. On the other hand, in -1.2 MPa PEG, the highest proline accumulations belonged to MR219-4, MR219-9 and MR219 (Figure 1). In parallel to the above results, other researchers have also approved the impact of PEG in the accumulation of proline in rice leaves and roots (Lum et al., 2014).

On the basis of correlation analysis, total germination showed a significant positive correlation with GR, G\%, GVI, plumule fresh weight, and radical length. The negative and nonsignificant correlations were found between total germination and $\mathrm{Fr}$, leaves and shoot proline content (Table 9). Furthermore, there were positive correlations between germination rate and some traits including G\%, GVI, plumule fresh weight as well as radical length were positive correlations (Table 9). The results of correlation analysis 
Figure 1. Effect of different polyethylene glycol (PEG) priming on the leaf and root proline contents of six indica rice varieties.
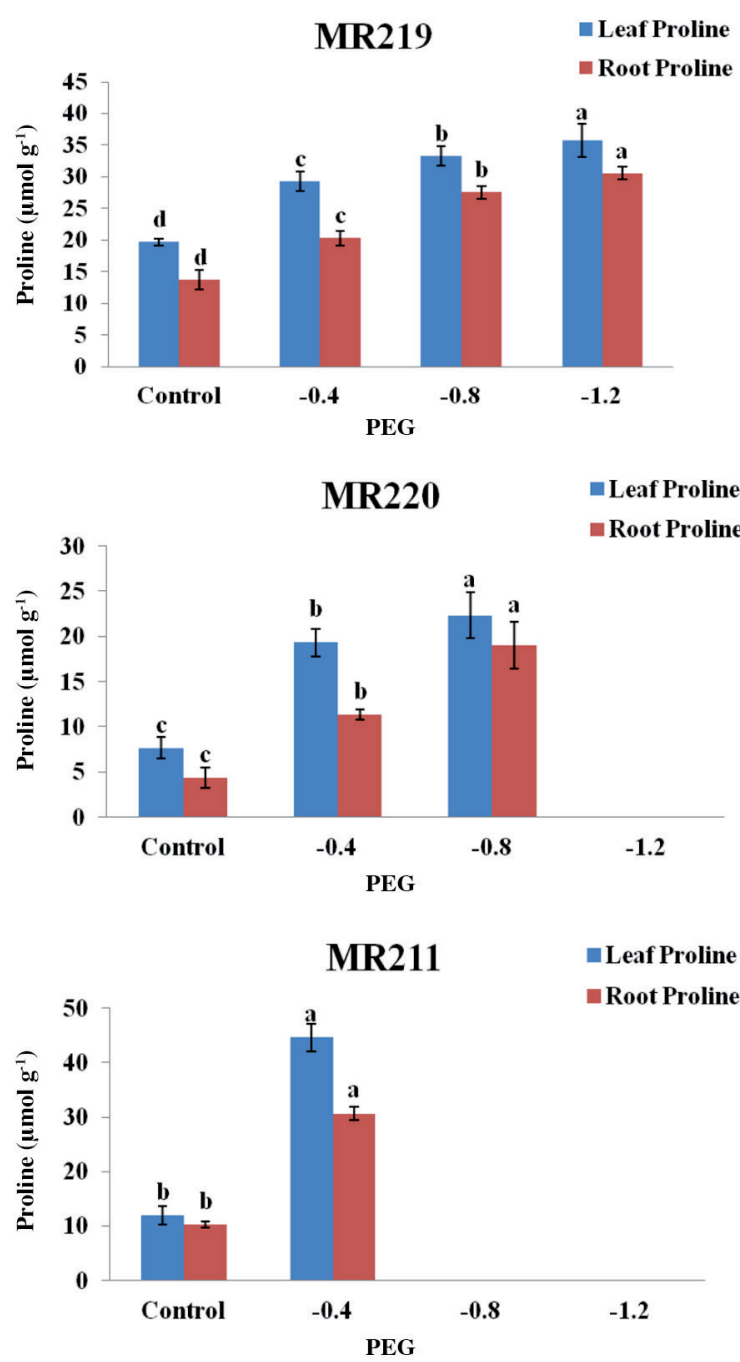
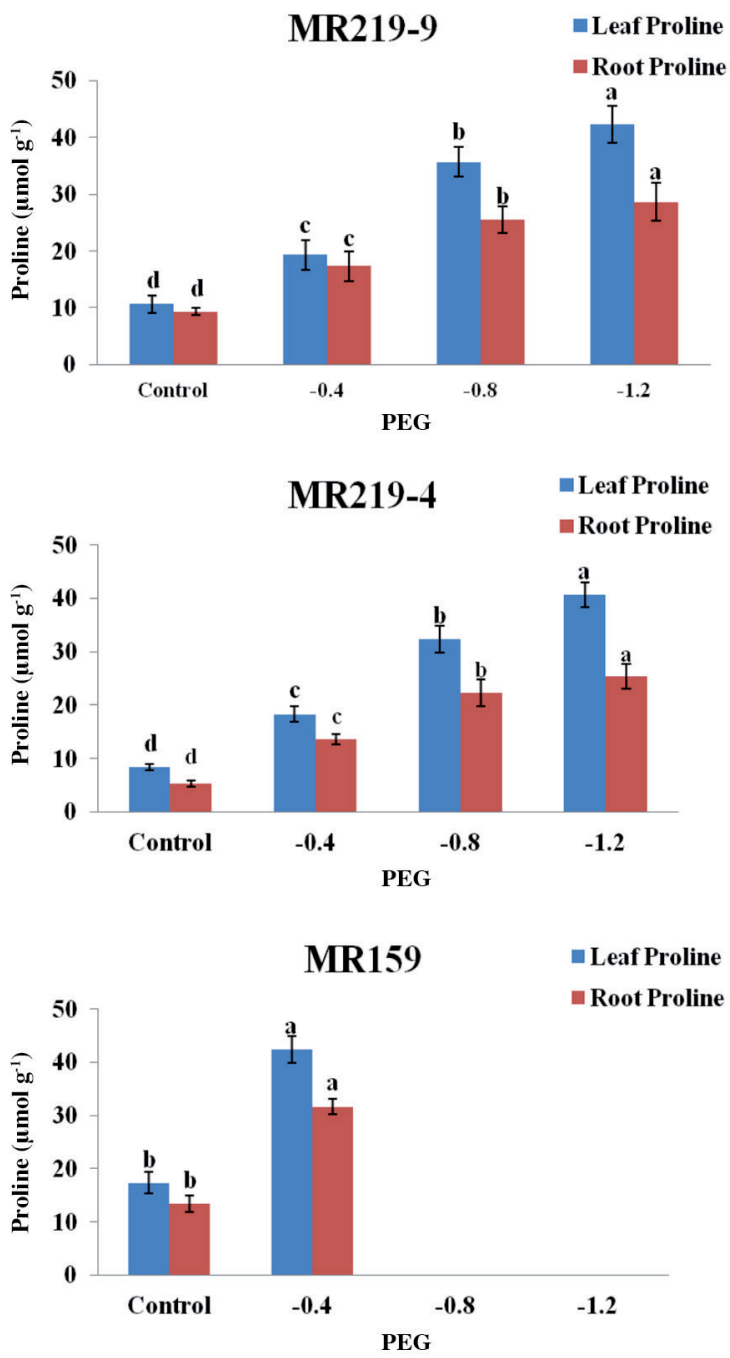

Different letters indicate significant difference among accessions using Duncan's multiple range tests at $\mathrm{p} \leq 0.01$.

between average germination time and relative frequency, leaves proline, shoot proline and ratio of leaves/root proline were figured out as significant and positive. The significant and positive correlations were found between G\% and GVI, plumule fresh weight as well as plumule and radical length. GVI and plumule fresh weight had a significant and positive

Table 9. Correlation coefficients of all the indica rice traits under polyethylene glycol (PEG) treatments.

\begin{tabular}{|c|c|c|c|c|c|c|c|c|c|c|c|c|c|c|c|c|}
\hline & TG & GR & AGT & AS & $\mathrm{G} \%$ & SVI & $\mathrm{Fr}$ & PFW & PDW & RFW & RDW & PL & $\mathrm{Rl}$ & LP & $\mathrm{RP}$ & $\mathrm{RP} / \mathrm{SP}$ \\
\hline TG & 1 & & & & & & & & & & & & & & & \\
\hline GR & $1^{* *}$ & 1 & & & & & & & & & & & & & & \\
\hline AGT & $0.19^{\mathrm{ns}}$ & $0.19^{\text {ns }}$ & 1 & & & & & & & & & & & & & \\
\hline AS & $0.52^{* *}$ & $0.52^{* *}$ & $0.29^{\text {ns }}$ & 1 & & & & & & & & & & & & \\
\hline $\mathrm{G} \%$ & $0.98^{* *}$ & $0.98^{* *}$ & $0.31^{\mathrm{ns}}$ & $0.59^{* *}$ & 1 & & & & & & & & & & & \\
\hline SVI & $0.88^{* *}$ & $0.88^{* *}$ & $0.16^{\mathrm{ns}}$ & $0.36^{*}$ & $0.88^{* * *}$ & 1 & & & & & & & & & & \\
\hline Fr & $-0.013^{\mathrm{ns}}$ & $-0.013^{\mathrm{ns}}$ & $0.93^{* *}$ & $0.22^{\mathrm{ns}}$ & $0.10^{\mathrm{ns}}$ & $-0.07^{\mathrm{ns}}$ & 1 & & & & & & & & & \\
\hline PFW & $0.77^{* *}$ & $0.77^{* *}$ & $0.35^{*}$ & $0.44^{* *}$ & $0.81^{* *}$ & $0.79^{* *}$ & $0.24^{\mathrm{ns}}$ & 1 & & & & & & & & \\
\hline PDW & $0.43^{* *}$ & $0.43^{* *}$ & $0.03^{\mathrm{ns}}$ & $0.32^{\text {ns }}$ & $0.40^{*}$ & $0.48^{* *}$ & $-0.06^{\mathrm{ns}}$ & $0.23^{\mathrm{ns}}$ & 1 & & & & & & & \\
\hline RFW & $0.42^{* *}$ & $0.42^{* *}$ & $0.41^{*}$ & $0.20^{\mathrm{ns}}$ & $0.52^{\text {*** }}$ & $0.58^{* *}$ & $0.35^{*}$ & $0.73^{* *}$ & $0.20^{\text {ns }}$ & 1 & & & & & & \\
\hline RDW & $0.18^{\text {ns }}$ & $0.18^{\mathrm{ns}}$ & $0.31^{* *}$ & $0.35^{*}$ & $0.22^{\mathrm{ns}}$ & $0.19^{\text {ns }}$ & $0.30^{\mathrm{ns}}$ & $0.18^{\text {ns }}$ & $0.55^{* *}$ & $0.39^{*}$ & 1 & & & & & \\
\hline PL (cm) & $0.57^{* *}$ & $0.57^{* *}$ & $0.49^{* *}$ & $0.71^{* *}$ & $0.65^{\text {*** }}$ & $0.53^{* *}$ & $0.42^{* *}$ & $0.49^{* *}$ & $0.48^{* *}$ & $0.50^{* *}$ & $0.51^{* *}$ & 1 & & & & \\
\hline $\mathrm{Rl}(\mathrm{cm})$ & $0.63^{* *}$ & $0.63^{* *}$ & $0.35^{*}$ & $0.53^{* *}$ & $0.70^{* *}$ & $0.74^{\mathrm{ns}}$ & $0.25^{\mathrm{ns}}$ & 0.67 & $0.47^{\text {** }}$ & $0.68^{* *}$ & $0.40^{*}$ & $0.9^{* *}$ & 1 & & & \\
\hline LP & $-0.23^{\mathrm{ns}}$ & $-0.23^{\mathrm{ns}}$ & $0.63^{* *}$ & $0.17^{\mathrm{ns}}$ & $-0.13^{\mathrm{ns}}$ & $-0.29^{\mathrm{ns}}$ & $0.70^{* *}$ & $-0.09^{\mathrm{ns}}$ & $-0.11^{\mathrm{ns}}$ & $0.22^{\mathrm{ns}}$ & $0.52^{* *}$ & $0.25^{\mathrm{ns}}$ & $0.016^{\mathrm{ns}}$ & 1 & & \\
\hline $\mathrm{RP}$ & $-0.25^{\mathrm{ns}}$ & $-0.25^{\mathrm{ns}}$ & $0.61^{* *}$ & $0.16^{\mathrm{ns}}$ & $-0.15^{\mathrm{ns}}$ & $-0.29^{\mathrm{ns}}$ & $0.67^{* *}$ & $-0.10^{\mathrm{ns}}$ & $-0.11^{\mathrm{ns}}$ & $0.21^{\mathrm{ns}}$ & $0.52^{* * *}$ & $0.24^{\mathrm{ns}}$ & $0.011^{\mathrm{ns}}$ & $0.99^{* *}$ & 1 & \\
\hline RP/SP & $0.52^{* *}$ & $0.52^{* *}$ & $0.66^{* *}$ & $0.80^{* *}$ & $0.61^{* *}$ & $0.36^{*}$ & $0.59^{* *}$ & $0.50^{* *}$ & $0.25^{\mathrm{ns}}$ & $0.34^{*}$ & $0.32^{\mathrm{ns}}$ & $0.75^{\text {** }}$ & $0.57^{* *}$ & $0.27^{\mathrm{ns}}$ & $0.23^{* *}$ & 1 \\
\hline
\end{tabular}

${ }^{*},{ }^{* *}$ Significant at the 0.05 and 0.01 probability levels, respectively. Ns: Nonsignificant.

TG: Total germination, GR: germination rate, AGT: average germination time, AS: average speed, G\%: germination percentage, SVI: seedling vigor index, Fr: relative frequency, PFW: plumule fresh weight, PDW: plumule dry weight, RFW: radical fresh weight, RDW: radical dry weight, PL: plumule length, RL: radical length, LP: leaf proline, RP: root proline, RP/SP: ratio of root to shoot proline. 
correlation. In contrast, GVI and Fr had nonsignificant and negative correlation. Interestingly, radical and plumule length parameters had a strong significant and positive correlation. In continuation of the analysis, the higher positive correlation of leaves and root proline parameters were observed between the mentioned traits and GR time, as well as relative frequency. Nonetheless, the highest significant correlation of the proline group was between leaves and root proline content (Table 9).

Linear regression analysis demonstrated a significant negative relationship between PEG levels and total germination, GR, GVI, plumule fresh weight, radical fresh weight, plumule length, and radical length (Table 9). On the other hand, linear regression showed a positive and significant relationship between PEG levels and proline content of leaves and roots in this experiment (Table 10). The regression analysis results of the present study are in agreement with other investigations under similar undesirable conditions (Ashkan and Jalal, 2013).

In this study, cluster analysis was used to determine the similarities of six rice varieties based on all measured traits produced by hydro-priming, hormonal priming, and PEG priming. The cut-off line of the cluster revealed three different groups. Cluster 1 holds three varieties (MR219-4 nr 2, MR219-9 nr 5, and MR219 nr 3), cluster 2 contained two varieties (MR211 nr 1 and MR159 nr 6) and and finally cluster 3 comprised one variety (MR220 nr 4) as shown in Figure 2.

\section{CONCLUSION}

The current study suggests that hydropriming for 18 and $12 \mathrm{~h}$ can be successfully applied to obtain higher seed germination and seedling vigor in indica rice varieties. Accordingly, it is concluded that seed hydropriming is an effective approach to increase seed germination of indica rice. In contrast, hormonal priming showed a fluctuating trend in different varieties in terms of seed germination. In addition, the outcomes of the present research means that polyethylene glycol (PEG) priming of the six indica rice seeds might be an effective technique to simulate germination-based feedback of rice seeds (seed vigor and establishment) in drylands.

Table 10. Relationship between polyethylene glycol (PEG) and total seed germination of six indica rice varieties.

\begin{tabular}{lccc}
\hline Parameters & $\begin{array}{c}\text { Linear regression } \\
\text { equation } \\
\text { (PEG) }\end{array}$ & $\begin{array}{c}\text { Regression } \\
\text { coefficient } \\
\left(\mathrm{R}^{2}\right)\end{array}$ & Probability \\
\hline Total germination & $3.4054-0.1537 \mathrm{x}$ & 0.7227 & 0.01 \\
Germination rate & $3.4055-1.845 \mathrm{x}$ & 0.7125 & 0.01 \\
Seedling vigor index & $3.063-0.0503 \mathrm{x}$ & 0.51 & 0.01 \\
Plumule fresh weight & $3.4039-27.73 \mathrm{x}$ & 0.55 & 0.01 \\
Radical fresh weight & $2.7653-19.53 \mathrm{x}$ & 0.082 & 0.01 \\
Plumule length & $3.6237-1.152 \mathrm{x}$ & 0.4072 & 0.01 \\
Radical length & $3.4144-3.9497 \mathrm{x}$ & 0.4603 & 0.01 \\
Leaf proline & $2.1457+0.0088 \mathrm{x}$ & 0.1449 & 0.01 \\
Root proline & $2.1337+0.0125 \mathrm{x}$ & 0.1587 & 0.01 \\
\hline
\end{tabular}

Figure 2. The cluster analysis of six indica rice varieties under hydro-priming, hormonal priming and polyethylene glycol priming.

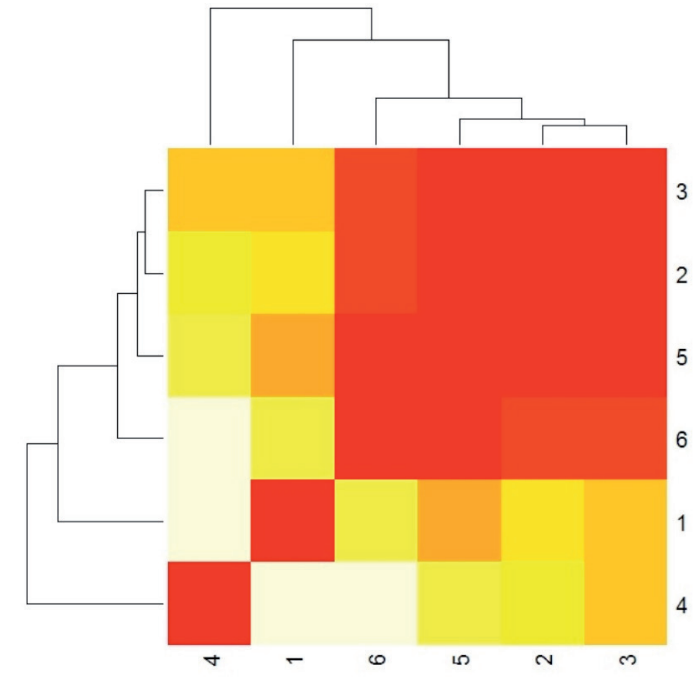

1: MR211, 2: MR219-4, 3: MR219, 4: MR220, 5: MR219-9, and 6: MR159.

\section{ACKNOWLEDGEMENTS}

The authors would like to appreciate the Long-term Research Grants Scheme (LRGS), Food Security Rice Research Program of the Ministry of Higher Education, Malaysia, for creating an opportunity to conduct the present review article.

\section{REFERENCES}

Abdul-Baki, A.A., and J.D. Anderson. 1973. Vigor determination in soybean seed by multiple criteria. Crop Science 13:630-633.

Afzal, I., S.M. Basra, and A. Iqbal. 2005. The effects of seed soaking with plant growth regulators on seedling vigor of wheat under salinity stress. Journal of Stress Physiology and Biochemistry 1:6-14.

Aguilar-Benítez, G., C.B. Peña-Valdivia, J.R. Vega, R. CastroRivera, and H.M. Ramírez-Tobías. 2014. Seed germination and early root growth in common bean and maize landraces and improved cultivars at different water stress levels. International Journal of Applied Science and Technology 4:118-127.

Anosheh, H.P., H. Sadeghi and Y. Emam. 2011. Chemical priming with urea and $\mathrm{KNO}_{3}$ enhances maize hybrids (Zea mays L.) seed viability under abiotic stress. Journal of Crop Science and Biotechnology 14:289-295.

Ashkan, A., and M. Jalal. 2013. Effects of salinity stress on seed germination and seedling vigor indices of two halophytic plant species (Agropyron elongatum and A. pectiniforme). International Journal of Agriculture and Crop Sciences 5:2669-2676.

Audi, A., and F. Muhktar. 2009. Effect of pre-sowing hardening treatments using various plant growth substances on cowpea germination and seedling establishment. Bayero Journal of Pure and Applied Sciences 2:44-48.

Bates, L., R. Waldren, and I. Teare. 1973. Rapid determination of free proline for water-stress studies. Plant and Soil 39:205-207.

Clune, T.S., and L. Copeland. 1999. Effects of aluminium on canola roots. Plant and Soil 216:27-33. 
Cothren, J.T., and D. Oosterhuis. 2010. Use of growth regulators in cotton production. p. 289-303. In Stewart, J., D. Oosterhuis, J. Heitholt, J.R. Mauney (eds). Physiology of cotton. Springer Netherlands, Dordrecht, The Netherlands.

Dennis, E., R. Dolferus, M. Ellis, M. Rahman, Y. Wu, F. Hoeren, et al. 2000. Molecular strategies for improving waterlogging tolerance in plants. Journal of Experimental Botany 51:89-97.

Ellis, R., and E. Roberts. 1980a. The influence of temperature and moisture on seed viability period in barley (Hordeum distichum L.) Annals of Botany 45:31-37.

Ellis, R., and E. Roberts. 1980b. Improved equations for the prediction of seed longevity. Annals of Botany 45:13-30.

Farooq, M., S. Basra, and K. Hafeez. 2006a. Seed invigoration by osmohardening in coarse and fine rice. Seed Science and Technology 34:181-187.

Farooq, M., S.M. Barsa, and A. Wahid. 2006b. Priming of fieldsown rice seed enhances germination, seedling establishment, allometry and yield. Plant Growth Regulation 49:285-294.

Gharoobi, B., M. Ghorbani, and M.G. Nezhad. 2012. Effects of different levels of osmotic potential on germination percentage and germination rate of barley, corn and canole. Iranian Journal of Plant Physiology 2:413-417.

Hamidi, R., and H. Pirasteh-Anosheh. 2013. Comparison effect of different seed priming methods on sunflower germination and seedling growth. International Journal of Agronomy and Plant Production 4:1247-1250.

Jamil, M., D.B. Lee, K.Y. Jung, M. Ashraf, S.C. Lee, and E.S. Rha. 2006. Effect of salt $(\mathrm{NaCl})$ stress on germination and early seedling growth of four vegetables species. Journal of Central European Agriculture 7:273-282.

Kareem, I., M.R. Ismail, A. Puteh, A.A. Rahim, S.H. Habib, and H. Kausar. 2013. Potential osmotic and hormonal priming for higher productivity of rice. Journal of Food, Agriculture and Environment 11:737-741.

Khodarahmpour, Z., M. Ifar, and M. Motamedi. 2014. Effects of $\mathrm{NaCl}$ salinity on maize (Zea mays L.) at germination and early seedling stage. African Journal of Biotechnology 11:298-304.

Labouriau, L.G., and A. Pacheo. 1978. On the frequency of isothermal germination in seeds of Dolichos biflorus L. Plant and Cell Physiology 19:507-512.

Lum, M., M. Hanafi, Y. Rafii, and A. Akmar. 2014. Effect of drought stress on growth, proline and antioxidant enzyme activities of upland rice. Journal of Animal and Plant Sciences 24:1487-1493.

Michel, B.E., and M.R. Kaufmann. 1973. The osmotic potential of polyethylene glycol 6000. Plant Physiology 51:914-916.

Nam, K.H., D.Y. Kim, H.J. Shin, K.J. Nam, J.H. An, I.S. Pack, et al. 2014. Drought stress-induced compositional changes in tolerant transgenic rice and its wild type. Food Chemistry 153:145-150.
Pant, B., and B. Bose. 2016. Mitigation of the influence of PEG-6000 imposed water stress on germination of halo primed rice seeds. International Journal of Agriculture, Environment and Biotechnology 9:275-281. doi:10.5958/2230732X.2016.00036.X.

Pittelkow, C.M., M.A. Adviento-Borbe, C. Kessel, J.E. Hill, and B.A. Linquist. 2014. Optimizing rice yields while minimizing yield-scaled global warming potential. Global Change Biology 20:1382-1393. doi:10.1111/gcb.12413.

Roberts, E., and R. Ellis. 1989. Water and seed survival. Annals of Botany 63:39-39.

Sikder, S., M. Hasan, and M. Hossain. 2009. Germination characteristics and mobilization of seed reserves in maize varieties as influenced by temperature regimes. Journal of Agriculture and Rural Development 7:51-58.

Szabados, L., and A. Savoure. 2010. Proline: a multifunctional amino acid. Trends in Plant Science 15:89-97.

Talei, D., A. Valdiani, M.P. Abdullah, and S.A. Hassan. 2012. A rapid and effective method for dormancy breakage and germination of King of Bitters (Andrographis paniculata Nees.) seeds. Maydica 57:98-105.

Tamaki, H., M. Reguera, Y.M. Abdel-Tawab, Y. Takebayashi, H. Kasahara, and E. Blumwald. 2015. Targeting hormone-related pathways to improve grain yield in rice: a chemical approach. PLoS ONE 10(6):e0131213. doi:10.1371/journal.pone.0131213.

Wahid, A., A. Noreen, S.M. Basra, S. Gelani, and M. Farooq. 2008. Priming-induced metabolic changes in sunflower (Helianthus annuus) achenes improve germination and seedling growth. Botanical Studies 49:343-350.

Wahyuni, S., U.R. Sinniah, R. Amarthalingam, and M.K. Yusop. 2003. Enhancement of seedling establishment in rice by selected growth regulators as seed treatment. Jurnal Penelitian Pertanian Tanaman Pangan 22:51-55.

Wahyuni, S., U.R. Sinniah, M.K. Yusop, and R. Amarthalingam. 2013. Improvement of seedling establishment of wet seeded rice using $\mathrm{GA}_{3}$ and IBA as seed treatment. Indonesian Journal of Agricultural Science 4(2):56-62.

Wang, W.S., Y.J. Pan, X.Q. Zhao, D. Dwivedi, L.H. Zhu, J. Ali, et al. 2010. Drought-induced site-specific DNA methylation and its association with drought tolerance in rice (Oryza sativa L.) Journal of Experimental Botany. doi:10.1093/jxb/erq391.

Xie, L., Z. Tan, Y. Zhou, R. Xu, L. Feng, Y. Xing, et al. 2014. Identification and fine mapping of quantitative trait loci for seed vigor in germination and seedling establishment in rice. Journal of Integrative Plant Biology 56:749-759. 